\title{
Heritabilitas Galur Padi Beras Hitam (Oryza sativa L) Hasil Seleksi Pedigree F1
}

\author{
Heritability of Black Rice (Oryza sativa L) Pedgree F1 Selection \\ I Gusti Putu Muliarta Aryana ${ }^{*}$, Bambang B. Santoso², AAK Sudharmawan', \\ Muhammad Sukri ${ }^{3}$ \\ ${ }^{1}$ Kelompok Peneliti Pengelolaan Sumberdaya Genetik Tanaman Padi Jagung dan Serealia, \\ Fakultas Pertanian Universitas Mataram \\ ${ }^{2}$ Kelompok Peneliti Pengembangan Pertanian Lahan Kering, \\ Fakultas Pertanian Universitas Mataram \\ ${ }^{3}$ Prodi Agroekoteknologi Fakultas Pertanian Universitas Mataram, \\ Jl. Majapahit,No.62, Mataram NTB,83125. INDONESIA \\ *corresponding author, email: muliartal@yahoo.co.id
}

Manuscript received: 02-05-2019. Accepted: 20-06-2019

\begin{abstract}
ABSTRAK
Penelitian ini bertujuan untuk mengetahui nilai heritabilitas karakter galur F1 padi beras hitam hasil seleksi pedigree F1. Metode yang digunakan adalah metode eksperimental dengan percobaan dilapangan. Percobaan dilakukan di Lahan Percobaan Fakultas Pertanian Universitas Mataram. Desa Nyur Lembang Kecamatan Narmada Kabupaten Lombok Barat, Provinsi NTB pada bulan Februari sampai Juni 2018, menggunakan acak kelompok (RAK) yang terdiri dari 40 perlakuan dengan dua ulangan sehingga diperoleh 80 unit percobaan. Data hasil pengamatan dianalisis dengan analisis keragaman (ANOVA). Hasil penelitian menunjukkan bahwa nilai duga heritabilitas tinggi ditunjukkan oleh karakter umur berbunga, tinggi tanaman, panjang malai, jumlah gabah berisi, dan berat 100 butir. Kriteria heritabilitas rendah di tunjukkan oleh jumlah anakan produktif, jumlah gabah hampa, berat gabah perumpun, dan hasil (ton.ha $\left.{ }^{-1}\right)$.
\end{abstract}

Kata kunci: Padi; Beras Hitam; Heritabilitas; Pedigree

\section{ABSTRACT}

This study aims to determine Heritability value of Flline of black rice characters result from pedigree selection. This research conducted by field experiment carried out at the research station of Faculty of Agriculture, University of Mataram. Nyur Lembang Village, Narmada District, West Lombok Regency, NTB Province from February to June 2018. This research empioyed Randomized Complete Blok Desing (RCBD) by 40 genotipes as treatments with replications, so there are 80 of experimental units. Observed data analized by analysis of variance (ANOVA). The result of research showed that high of heritability value gained from flowering age plant height, panicle length, number of grains filled, and 
weight of 100 grains. Low heritability criteria are shown by number of productive tillers, number of empty grains, weight of grains per clumpsand yield (ton.ha- ${ }^{-1}$ ).

Keyword: Black Rice lines; Heritability; Pedigree selection.

\section{PENDAHULUAN}

Padi beras hitam (Oryza sativa) merupakan salah satu jenis beras disamping beras merah dan beras putih. Saat ini beras hitam mulai popular dan banyak dikonsumsi oleh sebagian masyarakat sebagai bahan fungsional. Beras hitam memiliki kandungan antosianin yang sangat tinggi, antosianin telah diakui dapat mengurangi kadar kolesterol (Lee et al., 2008), mencegah kanker (Hyun dkk, 2004). Namun di samping kelebihan tersebut, padi beras hitam umumnya mempunyai kekurangan seperti umur tanaman panjang dan produktifitas yang rendah sehingga petani kurang tertarik dalam budidaya padi beras hitam.

Untuk memperbaiki sifat padi beras hitam tersebut telah dilakukan persilangan antara varietas unggul Situ Patenggang yang berwarna beras putih, memiliki umur tanaman genjah dan potensi hasil yang tinggi dengan varietas local beras hitam "Baas Selem" yang berdaya hasil rendah namun memiliki kandungan antosianin. Dari hasil persilangan tersebut diharapkan diperoleh padi beras hitam bedaya hasil tinggi serta berumur genjah (Muliarta dkk, 2017). Untuk menghasilkan suatu varietas unggul perlu dipelajari mengenai parameter genetik seperti keragaman genetik dan heritabilitas.

Nilai duga heritabilitas dapat diduga dengan membandingkan besarnya ragam genetik total terhadap fenotip (Aidi-Daslin et al., 2008). Nilai duga heritabilitas yang tinggi menunjukkan faktor genetik lebih berperan dalam mengendalikan suatu sifat dibandingkan dengan faktor lingkungan (Barmawi et al., 2013). Heritabilitas (daya waris) menentukan kemajuan seleksi, makin besar nilai heritabilitas makin besar pula kemajuan seleksi. Karakter seleksi harus memiliki keragaman dan heritabilitas yang tinggi agar di peroleh target kemajuan seleksi (Lubis et al., 2014).

Menurut Barmawi et al., (2013), keragaman genetik dan heritabilitas bermanfaat untuk menduga kemajuan genetik dari seleksi. Oleh karena itu seleksi pedigree pada populasi F1 hasil persilangan padi beras hitam dengan padi beras putih dapat memberi petunjuk nilai harapan kemajuan genetik yang tinggi, jika sifat yang dilibatkan dalam seleksi memiliki keragaman genetik dan heritabilitas yang tinggi. Dengan demikian, seleksi diharapkan menghasilkan kemajuan genetik yang tinggi untuk beberapa karakter agronomi yang diinginkan.

Proses perakitan suatu varietas unggul umumnya berlangsung empat hingga lima tahun. Dewi $d k k$. . (1996) menyatakan bahwa pemuliaan konvensional membutuhkan enam sampai delapan generasi dalam satu siklus pemuliaan untuk memperoleh galur murni. Metode persilangan yang digunakan dalam mendapatkan varietas unggul salah satunya melalui metode seleksi pedigree. Berdasarkan uraian diatas, maka perlu dilakukan penelitian tentang Heritabilitas Galur Padi Beras Hitam (Oryza sativa) Hasil Seleksi pedigree F1. Tujuan penelitian ini adalah untuk mengetahui nilai heritabilitas karakter kuantitatif galur padi beras hitam (Oryza sativa) hasil seleksi pedigree F1. 


\section{BAHAN DAN METODE}

Percobaan dilaksanakan pada MH/MK mulai Februari-Juni 2018 di Kebun Percobaan Fakultas Pertanian Universitas Mataram, Desa Nyurlembang, Kecamatan Narmada, Kabupaten Lombok Barat. Metode penelitian yang digunakan adalah metode eksperimental dengan percobaan lapang. Percobaan dirancangan menggunakan Rancangan Acak Kelompok (RAK) yang terdiri atas 40 perlakuan yaitu 38 galur padi beras hitam, dan 2 tetua (Situ Patenggang dan Baas Selem) (Tabel 1). Setiap perlakuan diulang 2 kali, sehingga diperoleh 80 unit percobaan.

Tabel 1. Nama genotipe padi yang digunakan dalam penelitian

\begin{tabular}{|c|c|c|c|c|c|c|c|}
\hline No & $\begin{array}{l}\text { Perlaku- } \\
\text { an }\end{array}$ & $\begin{array}{l}\text { Genotipe } \\
\text { Asal }\end{array}$ & Warna Gabah & No & $\begin{array}{l}\text { Perlaku- } \\
\text { an }\end{array}$ & $\begin{array}{l}\text { Genotipe } \\
\text { Asal }\end{array}$ & Warna Gabah \\
\hline 1 & G1 & F9 1/1/6/I & Kuning kehitaman & 21 & $\mathrm{G} 21$ & F9 3/2/1/1/I & Kuning Kehitaman \\
\hline 2 & G2 & F9 $1 / 1 / 2 / \mathrm{II}$ & Kuning Kehitaman & 22 & G22 & F9 3/2/1/7/I & Kuning Kehitaman \\
\hline 3 & G3 & F9 2/1/1/4/I & Kuning Kehitaman & 23 & G23 & F9 2/3/2/II & Kuning Kehitaman \\
\hline 4 & G4 & F9 2/1/1/5/I & Kuning Kehitaman & 24 & G24 & F9 2/3/6/II & Kuning Kehitaman \\
\hline 5 & G5 & F9 2/1/1/6/I & Kuning Kehitaman & 25 & G25 & F9 2/3/1/IIII & Kuning Kehitaman \\
\hline 6 & G6 & F9 2/1/1/1/II & Kuning Kehitaman & 26 & G26 & F9 2/3/2/III & Kuning Kehitaman \\
\hline 7 & G7 & F9 2/1/1/5/II & Kuning Kehitaman & 27 & G27 & F9 2/3/9/III & Kuning Kehitaman \\
\hline 8 & G8 & F9 2/1/2/1/I & Kuning kehitaman & 28 & G28 & F9 $1 / 4 / 5 / I$ & Kuning Kehitaman \\
\hline 9 & G9 & F9 $2 / 1 / 2 / 2 / \mathrm{I}$ & Kuning Kehitaman & 29 & G29 & F9 1/4/6/I & Kuning Kehitaman \\
\hline 10 & G10 & F9 $2 / 1 / 2 / 3 / \mathrm{I}$ & Kuning Kehitaman & 30 & G30 & F9 $1 / 4 / 7 / 1$ & Kuning Kehitaman \\
\hline 11 & G11 & F9 2/1/2/7/I & Kuning Kehitaman & 31 & G31 & F9 1/4/2/II & Kuning Kehitaman \\
\hline 12 & $\mathrm{G} 12$ & F9 2/1/2/9/I & Kuning Kehitaman & 32 & G32 & F9 1/4/1/III & Kuning Kehitaman \\
\hline 13 & G13 & F9 3/1/2/II & Hitam & 33 & G33 & F9 3/4/2/5/I & Hitam \\
\hline 14 & G14 & F9 3/1/5/II & Hitam & 34 & G34 & F9 3/4/1/2/I & Hitam \\
\hline 15 & G15 & F9 3/1/9/II & Hitam & 35 & G35 & F9 3/4/1/3/I & Hitam \\
\hline 16 & G16 & F9 3/1/10/II & Hitam & 36 & G36 & F9 3/4/1/4/I & Hitam \\
\hline 17 & G17 & F9 3/2/2/4/I & Kuning Kehitaman & 37 & G37 & F9 3/4/1/4/II & Hitam \\
\hline 18 & G18 & F9 3/2/2/5/I & Kuning Kehitaman & 38 & G38 & F9 3/4/1/5/II & Hitam \\
\hline 19 & G19 & F9 3/2/2/7/I & Kuning Kehitaman & 39 & G39 & Baas Selem & Hitam \\
\hline \multirow[t]{2}{*}{20} & G20 & F9 3/2/2/2/II & Kuning Kehitaman & 40 & G40 & Situ & Kuning \\
\hline & & & & & & Paten & \\
\hline
\end{tabular}

Penanaman dilakukan dengan sistim sawah irigasi pada umur bibit 21 hari setelah semai (HSS) pada jarak tanam $25 \mathrm{~cm}$ x $25 \mathrm{~cm}$ dengan jumlah 1 tanaman per jarak tanam. Pemupukan dasar dilakukan pada umur 7 hst dengan menggunakan Phonska dosis 300 kg.ha ${ }^{-1}$, pupuk susulan pertama dengan Urea diberikan pada umur 30 hst dan pemupukan susulan ke 2 diberikan pada umur 50 hst dengan dosis masing-masing 100 kg.ha ${ }^{-1}$. Penyiangan dan pengendalian hama dilakukan secara optimum.

Pengamatan dilakukan dengan pengambilan tanaman sampel sebanyak 10 tanaman per unit percobaan yang dilakukan secara acak. Variabel yang diamati meliputi umur panen (hst), tinggi tanaman $(\mathrm{cm})$, jumlah anakan produktif per rumpun (batang), panjang malai $(\mathrm{cm})$, jumlah gabah berisi per malai (butir), jumlah gabah hampa per malai (butir), bobot 100 butir (gram), dan hasil gabah (ton.ha ${ }^{-1}$ ). 
Data hasil pengamatan dianalisis dengan menggunakan analisis keragaman pada taraf nyata 5\% (Singh and Chaudhary 1979) sebagai berikut:

Tabel 2. Analisis Keragaman untuk Rancangan Acak Kelompok

\begin{tabular}{llll}
\hline $\begin{array}{l}\text { Sumber } \\
\text { Keragaman }\end{array}$ & $\begin{array}{l}\text { Derajat } \\
\text { bebas }\end{array}$ & $\begin{array}{l}\text { Jumlah } \\
\text { Kuadrat }\end{array}$ & $\begin{array}{l}\text { Kuadrat } \\
\text { Tengah }\end{array}$ \\
\hline Blok & $(\mathrm{r}-1)$ & $\mathrm{JK}_{\mathrm{B}}$ & $\mathrm{KT}_{\mathrm{B}}$ \\
Genotipe & $(\mathrm{g}-1)$ & $\mathrm{JK}_{\mathrm{G}}$ & $\mathrm{KT}_{\mathrm{G}}$ \\
Galat & $(\mathrm{g}-1)(\mathrm{r}-1)$ & $\mathrm{JK}_{\mathrm{E}}$ & $\mathrm{KT}_{\mathrm{E}}$ \\
\hline Total & $\mathrm{g}-1$ & $\mathrm{JK}_{\mathrm{T}}$ & \\
\hline
\end{tabular}

Keterangan: $r$ : ulangan; $g$ : genotipe

Untuk menghitung nilai heritabilitas arti luas menggunakan rumus sebagai berikut (Syukur et al., 2012):

$$
\begin{aligned}
& H^{2}=\frac{\sigma^{2} G}{\sigma^{2} F} \text { atau } H^{2}=\frac{\sigma^{2} G}{\sigma^{2} G+\sigma^{2} E} \\
& \sigma^{2} G=\frac{K T G-K T E}{\text { Ulangan }} \\
& \sigma^{2} E=K T E
\end{aligned}
$$

Keterangan $: H^{2}=$ Heritabilitas

$\sigma^{2} G=$ Ragam genotipe

$\sigma^{2} F=$ Ragam Fenotipe

$\sigma^{2} E=$ Ragam lingkungan

Menurut Mangoendidjojo (2003) heritabilitas digolongkan menjadi tiga: heritabilitas rendah $\left(h^{2}<0.2\right)$, heritabilitas sedang $\left(0.2<\mathrm{h}^{2}<0.5\right)$, dan heritabilitas tinggi $\left(\mathrm{h}^{2}>0.5\right)$.

\section{HASIL DAN PEMBAHASAN}

Kisaran hasil , nilai heritabilitas dan kreteria heritabilitas galur-galur padi beras hitam hasil persilangan antara varietas unggul nasional Situ Patenggang dengan varietas local padi beras hitam "Baas Selem" yang kemudian dilakukan seleksi pedigree F1 untuk karakter umur berbunga, umur panen, tinggi tanaman, jumlah anakan produktif, panjang malai, jumlah gabah berisi dan hampa, bobot 100 butir, bobot gabah per rumpun, dan hasil dapat dilihat pada Tabel 3.

Pada Tabel 3 tampak bahwa nilai heritabilitas berkisar antara 23.4\% sampai dengan $86.8 \%$. Umur berbunga berkisar antara 75 sampai dengan 88 hari setelah tanam (hst), umur panen berkisar antara 106 sampai dengan 118 hari setelah tanam (hst). Kisaran tinggi tanaman antara 111 sampai dengan $118 \mathrm{~cm}$, panjang malai berkisar 22 sampai dengan $29 \mathrm{~cm}$, jumlah gabah berisi berkisar 92 sampai dengan 185 butir, berat 100 butir berkisar 2.45 sampai dengan 2.89 gram, dengan nilai heritabilitas berturut-turut yaitu 86.8\%; 86.8\%; 76.4\%; 72.4\%; 74.1\% dan $66.0 \%$. Jumlah anakan produktif berkisar 12 sampai dengan 25 batang, jumlah gabah 
hampa berkisar 17 sampai dengan 88 butir, berat gabah per rumpun berkisar 40.9 sampai dengan 67.2 gram dan hasil berkisar 2.88 sampai dengan 8.51 ton/ha. Nilai heritabilitas berturut-turut yaitu $46.9 \%$; 35.9\%; $23.4 \%$ dan $48.5 \%$. Karakter dengan nilai heritabilitas tinggi menunjukkan bahwa peran genetiknya lebih besar dari lingkungan. Sebaliknya karakter dengan heritabilitas sedang lebih dipengaruhi oleh faktor lingkungan daripada genetik.

Tabel 3. Nilai heritabilitas dalam arti luas pada semua sifat kuantitatif

\begin{tabular}{cllcc}
\hline No & Karakter & Angka/kisaran & Heritabilitas \% & Kriteria \\
\hline 1 & Umur Berbunga & $75-88 \mathrm{hst}$ & 86.8 & Tinggi \\
2 & Umur Panen & $106-118 \mathrm{hst}$ & 86.8 & Tinggi \\
3 & Tinggi Tanaman & $111-138 \mathrm{~cm}$ & 76.4 & Tinggi \\
4 & Jumlah Anakan Produktif & $12-25 \mathrm{batang}$ & 46.9 & Sedang \\
5 & Panjang Malai & $22-29 \mathrm{~cm}$ & 72.4 & Tinggi \\
6 & Jumlah Gabah Berisi & $92-185 \mathrm{butir}$ & 74.1 & Tinggi \\
7 & Jumlah Gabah Hampa & $17-88 \mathrm{butir}$ & 35.9 & Sedang \\
8 & Bobot 100 butir & $2.45-2.89$ gram & 66.0 & Tinggi \\
9 & Bobot Gabah per rumpun & $40.9-67.2$ gram & 23.4 & Sedang \\
10 & Hasil & $2.88-8.51$ ton/ha & 48.5 & Sedang \\
\hline
\end{tabular}

Keterangan: Nilai duga heritabilitas tinggi dan nilai duga heritabilitas sedang (Mangoendidjojo, 2003)

Nilai heritabilitas menggambarkan seberapa kuat sumbangan faktor genetik terhadap kenampakan dari suatu tanaman. (Limbongan 2008) menyebutkan bahwa nilai duga heritabilitas sangat menentukan keberhasilan seleksi untuk lingkungan yang sesuai. Mangoendidjojo (2003) mengelompokkan nilai heritabilitas dalam arti luas menjadi tiga kelas: nilai heritabilitas tinggi jika nilainya lebih dari 0.5 ; nilai heritabilitas sedang berkisar antara 0.2-0.5 dan heritabilitas rendah jika kurang dari 0.2.

Karakter yang memiliki nilai heritabilitas tinggi menunjukkan bahwa penampilan karakter tersebut lebih banyak dikendalikan oleh faktor genetik. Dengan demikian penampilan karakter umur berbunga, umur panen, tinggi tanaman, panjang malai, jumlah gabah berisi, berat 100 butir gabah dari galur-galur padi beras hitam yang diamati merupakan karakter sebenarnya yang diwariskan secara genetik karena memiliki nilai heritabilitas yang tinggi.

Nilai duga heritabilitas paling tinggi adalah umur berbunga dan umur panen berbeda tidak nyata yaitu $86.8 \%$. Hal ini mengindikasikan karakter umur berbunga dan umur panen lebih dipengaruhi oleh faktor genetik sehingga pewarisan sifat pada generasi selanjutnya (F2) cukup besar karena memiliki nilai heritabilitas tinggi yang mudah diwariskan.

Nilai duga heritabilitas sedang ditunjukkan oleh karakter jumlah anakan produktif, jumlah gabah hampa, berat gabah per rumpun, dan hasil ton.ha ${ }^{-1}$. Hal ini berarti bahwa penampilan dari galur galur padi beras hitam tersebut dikendalikan oleh faktor genetik dan faktor lingkungan, namun nilai duga heritabilitas sedang faktor lingkungan lebih besar pengaruhnya daripada faktor genetik. Nilai heritabilitas berimplikasi pada efisiensi seleksi dan pemilihan metode seleksi yang akan digunakan. Efisiensi seleksi ditentukan oleh karakter seleksi yang digunakan, dimana karakter seleksi dipilih berdasarkan nilai heritabilitas yang 
tinggi (Suwarno et al.,2016). Dalam hubungannya dengan seleksi adalah jika nilai heritabilitas tinggi maka metode seleksi yang cocok diterapkan adalah metode pedigree, Heritabilitas menentukan kemajuan seleksi, semakin besar nilai heritabilias semakin besar nilai kemajuan seleksi yang diraihnya dan semakin cepat varietas unggul dilepas. Sebaliknya semakin rendah nilai heritabilitas semakin kecil kemajuan seleksi diperoleh dan semakin lama varietas unggul baru dilepas

\section{KESIMPULAN}

Nilai duga heritabilitas tinggi ditunjukkan oleh karakter umur berbunga, umur panen, tinggi tanaman, panjang malai, jumlah gabah berisi dan berat 100 butir gabah yang berarti penampilan karakter tersebut disebabkan oleh faktor genetik. Kriteria heritabilitas sedang ditujukkan oleh jumlah anakan produktif, jumlah gabah hampa, berat gabah per rumpun, dan hasil (ton/ha) yang berarti penampilan karakter tersebut disebabkan oleh faktor genetik dan lingkungan.

\section{Ucapan Terima Kasih}

Ucapan terima kasih disampaikan kepada Dirjen Pendidikan Tinggi, Departemen Riset, Teknologi, dan Pendidikan Tinggi Republik Indonesia yang telah mendanai penelitian ini melalui skim PTUPT (Penelitian Terapan Unggulan Perguruan Tinggi) tahun 2018, atas nama I Gusti Putu Muliarta Aryana dan kawan kawan.

\section{DAFTAR PUSTAKA}

Aidi-Daslin, Sayurandi, dan S. Woelan. 2008. Keragaman genetik, heritabilitas dan korelasi berbagai karakter dengan hasil pada tanaman karet. J. Penelitian Karet 26(1):1-9.

Barmawi, M., A. Yushardi, dan N. Sa'diyah. 2013. Daya waris dan harapan kemajuan seleksi karakter agronomi kedelai Generasi F2 hasil persilangan antara Yellow bean dan Taichung. J. Agrotek Tropika 1(1):20-24.

Dewi I. S. D. Suwardi dan I. Ridwan. 1996. Galur padi hitam hasil kultur antera -Warta Penelitian dan Pengembangan Pertanian. 32(2):16-17.

Hyun, J.W. and H.S. Chung. 2004. Cyanidinand malvidin from Oryza sativa cv. Heugjinjubyeo mediate cytotoxicity againts human monocytic leukemia cells by arrest of G(2)/M phase andinduction of apoptosis. J. Agric. Food Chem. 52:2213-2217.

Lee, J.C., J.D. Kim, F.H. Hsieh, and J.B. Eun. 2008. Production of black rice cake using ground black rice and medium-grain brown rice. Int. J. Food Sci. Tech. 43(6):1078-1082.

Lubis, K., S.H. Sutjahjo, M. Syukur, dan Trikoesoemaningtyas. 2014. Pendugaan parameter genetik dan seleksi karakter morfofisiologi galur jagung introduksi di lingkungan tanah masam. J. Penelitian Pertanian Tanaman Pangan 33(2): 122- 128.

Mangoendidjojo, W. 2003. Dasar-Dasar Pemuliaan Tanaman. Kanisius. Yogyakarta.

Muliarta, IGP, Santoso BS, Sudharmawan, AAK, 2017. Perakitan varietas unggul padi beras hitam berdaya hasil tinggi serta berumur genjah. Hasil penelitai tidak di publikasikan

Singh, R.K. and B.D. Chaudary. 1979. Biometrical methods in quantitative genetic analysis, Kalyani Publishers. New Delhi. 304 p. 
Syukur M., Sujiprihati S., Yunianti, R., Kusumah, A.A. 2011. Pendugaan ragam genetic dan heritabilita karakter komponen hasil beberapa genotype cabai. J. Agrivigor 10 (2): 148156.

Suwarno P., M. Wirnas D., dan Junaedi A. 2016. Kendali Genetik Toleransi Kekeringan Pada Sawah (Oryza Sativa L.) J. Agron. 44 (2): 119-125. 